7 Gheiratmand R, Navipour R, Mohebbi M, Mallik A. Uncertainty on the number of HIV/AIDS patients: our experience in Iran. Sex Transm Infect number of HIV/

8 Kallajieh W. Epidemiology of human immunodeficiency virus and acquired immunodeficiency syndrome in Lebanon from 1984 through 1998. Int J Infect Dis 2000;4:209-13

9 Jahani M, Alavian S, Shirzad H, Kabir A, Hajarizadeh B. Distribution and risk factors of hepatitis $\mathrm{B}$, hepatitis $\mathrm{C}$, and HIV infection in a female population with "illegal social behaviour". Sex Transm Infect 2005;81:185.

10 Elmir E, Nadia S, Ouafae B, Rajae M, Amina S, Rajae E. HIV epidemiology in Morocco: a nine-year survey (1991-1999). Int If STD AIDS 2002;13:839-42.

11 Hashim M, Salih M, el Hag A, Karrar Z, Osman E, el Shiekh F, et al. AIDS and HIV infection in Sudanese children: a clinical and epidemiological study. AIDS Patient Care STDS 1997;11:331-7.

12 Joint United Nations Programme on HIV/AIDS and World Health Organization. AIDS epidemic update 2006. Geneva: UNAIDS, 2006.

13 Lenton C. Will Egypt escape the AIDS epidemic? Lancet 1997;349:1005.

14 Chemtob D. Epidemiology of HIV infection among Israeli Arabs. Public Health 2005;119:138-43.

15 Yassin K, Awad R, Tebi A, Queder A, Laaser U. A zero prevalence of antiHIV in blood donors in Gaza: how can it be sustained? AIDS 2001;15:936-7

16 Zawawi T, Abdelaal M, Mohamed A, Rowbottom D, Alyafi W, Marzouki K, et al. Routine preoperative screening for human immunodeficiency virus in a general hospital, Saudi Arabia. Infect Control Hosp Epidemiol 1997;18:158-9.
17 Heikel J, Sekkat S, Bouqdir F, Rich H, Takourt B, Radouani F, et al. The prevalence of sexually transmitted pathogens in patients presenting to a Casablanca STD clinic. Eur J Epidemiol 1999;15:711-5.

18 Jenkins C, Robalino D. Overview of the HIV/AIDS situation in the Middle East and North Africa and Eastern Mediterranean region. Why waiting to intervene can be costly. Washington DC: World Bank, 2003.

19 Gray PB. HIV and Islam: is HIV prevalence lower among Muslims? Soc Sci Med 2004:58(9):1751-6.

20 DeJong J, Jawad R, Mortagy I, Shepard B. The sexual and reproductive health of young people in the Arab countries and Iran. Reprod Health Matters 2005;13:49-59.

21 Ersilia F. Aids in contemporary Islamic ethical literature. Med Lau 2002;21:381-94

22 Ali S. AIDS and Muslim communities: opening up. AIDS STD Health Promot Exch 1996:13-6.

23 Khattab H. Socio-cultural and environmental factors and the context of women's vulnerability and risk to HIV infection in the MENA region. Slides presented at the UNAIDS regional meeting on Women, Girls, and HIV/AIDS in the Middle East and North Africa, Amman Jordan, 21-3 Feb 2005 .

24 El-Feki S. Middle-Eastern AIDS efforts are starting to tackle taboos. Lancet 2006;367:975-6.

(Accepted 27 September 2006)

doi 10.1136/bmj.38994.400370.7C

\title{
Tackling social determinants of health through community based initiatives
}

\author{
M Assai, S Siddiqi, S Watts \\ Women are often the key to improving a population's health, and this is especially true in the \\ Eastern Mediterranean region. Projects that empower women and provide basic needs are \\ transforming poor communities
}

Community Based Initiative Unit, Eastern

Mediterranean

Regional Office,

World Health

Organization,

Nasir City 11371,

Cairo, Egypt

M Assai

regional adviser

Health Policy and

Planning Unit,

Eastern

Mediterranean

Regional Office

S Siddiqi

regional adviser

S Watts

coordinator, social

determinants of health

Correspondence to:

S Siddiqi

siddiqis@

emro.who.int

BMJ 2006;333:854-6
Many of the inequalities in health, both within and between countries, are due to inequalities in the social conditions in which people live and work. ${ }^{1}$ These social determinants have a important effect on health status and general wellbeing. Tackling these underlying causes of poor health can contribute to improving health and health equity. ${ }^{2}$ The World Health Organization has given this approach added impetus by the creation of the Commission on Social Determinants of Health. Over the past two decades the basic development needs programme, a component of the community based initiatives programme in the WHO Eastern Mediterranean region, has developed and implemented community based initiatives to improve health in poor populations through actions on social determinants. The basic needs development programmes, which enhance the status of women and their role in the health of families, are an important part of this work.

\section{Gender and health}

The low status of women in the Eastern Mediterranean region is one of the key underlying social determinants of health. Sex differences in access to health care and poor health indicators for women and girls in several countries have resulted in differences in mortality and morbidity between male and female infants, ${ }^{3}$ differences in the quality of care for male and female children, ${ }^{4}$ high maternal mortality (estimated at 1600 deaths per 100000 live births in Afghanistan and Somalia), ${ }^{5}$ limited prenatal and postnatal care and lack of skilled attendants at birth, ${ }^{6}$ higher prevalence of mental illness among women than men, ${ }^{78}$ and high rates of suicide and attempted suicide among women of reproductive age. ${ }^{9}$

Gender determinants that have an adverse effect on the health of girls and women include low valuation of girls compared with boys and of women compared with men; social structure and beliefs that tolerate violence against women and children ${ }^{10-12}$; limited autonomy for women in making choices about treatment for their children or themselves ${ }^{13}$; and considerations of family honour that are associated with early marriage for girls and female genital mutilation. $^{14}{ }^{15}$

\section{Basic development needs programmes}

The basic development needs programmes help to enable women by giving them the opportunity to earn money through loans and training. The programmes also include measures to improve health and wellbeing such as health services, nutrition, safe water, sanitation, and shelter. The first programme was initiated in Somalia in 1988, and the model has been extended to support community development in 12 countries in the WHO Eastern Mediterranean region: Afghanistan, Djibouti, Egypt, Iran, Iraq, Lebanon, Morocco, Oman, Pakistan, Somalia, Sudan, and Yemen. Programmes now cover a population of almost three million in over 250 sites.

Further information on basic development needs programme is on bmj.com 


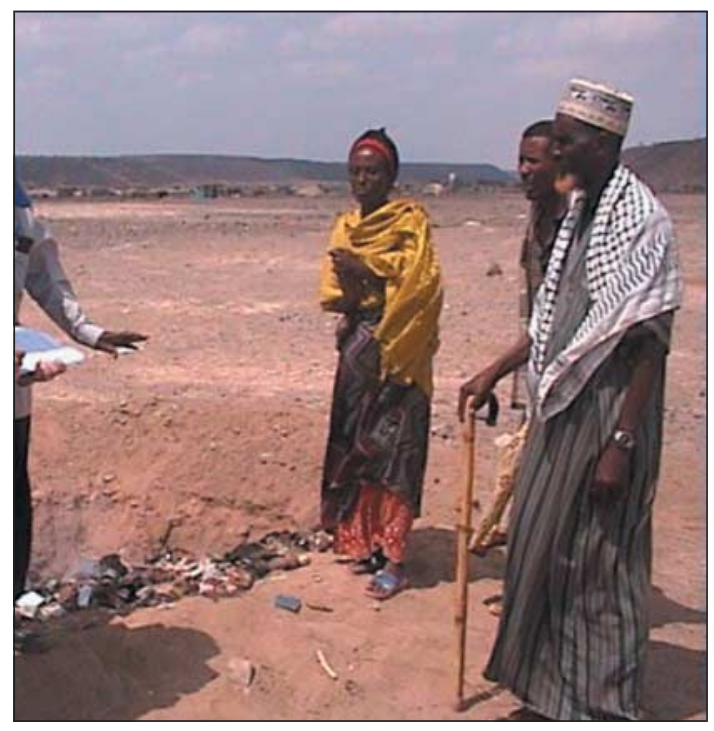

Rubbish disposal initiative in Djibouti

The programmes strongly emphasise community involvement and intersectoral collaboration, facilitated by WHO linkages with ministries of health (see bmj.com). Intersectoral coordination encourages government departments to work together, mobilises communities, and involves them in the development process. Intervention sites are identified in response to a request from the local residents. Each village is divided into clusters of 25 to 40 households. Each cluster elects one representative. The cluster representatives then nominate a village development committee. An intersectoral technical team provides training and back-up support and helps conduct a baseline survey. Each household is asked to identify their top three social development priorities. The final interventions are decided by the community on a consensus basis.

WHO has a catalytic role, providing soft loans against small scale income generating projects and for social uplift projects such as water supply and sanitation. The loans are usually $\$ 10000-\$ 50000$ ( $5000-£ 30000$; €8000-€40 000) for each site, to which the community contributes $25 \%$, and WHO supports about 25 new sites annually. The beneficiaries of the loan contribute $5 \%$ towards a community development fund that promotes health, social, and environmental activities in the village. Loans are returned in monthly installments once the project has reached maturation. The default rate is below $10 \%$. The amount returned is retained within the community as a revolving fund. Local non-governmental and community based organisations also fund projects using this approach.

\section{Effect of basic development needs programmes}

The experiences of two villages, Dar Mali in Atbara State, Sudan, and Gallamo in Djibouti show how the villagers have been able to bring about the change through simple community based interventions (box and bmj.com). ${ }^{16}{ }^{17}$

Programmes have been evaluated in Djibouti, Pakistan, Sudan, Yemen, and Iran. ${ }^{19} 19$ These show that the literacy and vocational training centres for women contribute to improvements in maternal care, family planning, and immunisation coverage for children (see

\section{Basic development needs programme in Dar Mali, Sudan ${ }^{16}$}

The village has a population of over 2000 and the programme was started in 1998. Since then the community has:

- Constructed a safe drinking water supply to cover the whole village

- Developed a rubbish disposal system using local resources such as donkey carts

- Established a community based health information system, which collects and analyses data and facilitates planning and management of health and development programmes

- Rehabilitated the secondary school, obtaining $\$ 134000$ from the state government to construct new classrooms, establish a laboratory, and buy chairs and desks

- Established a youth development centre with $\$ 10000$ from the government At present 285 small income generating initiatives are being implemented in the village. Poor members of the community have been provided with impregnated bed nets for prevention of malaria. Female cluster representatives have been trained on maternal and child care and are actively promoting health and educational activities.

bmj.com). Formal and community evaluations have identified several strengths of the programmes including well organised, aware, and enthusiastic communities; active participation of women in income generating activities; empowered communities that feel confident in approaching local governments and other agencies for new projects; and better health coverage indicators. Neighbouring communities have also been encouraged to organise themselves and make efforts to raise funds for social development projects.

\section{Challenges and opportunities}

The two major challenges for these programmes are sustainability of the existing projects and scaling them up to national level. War and civil strife have prevented the governments in Afghanistan, Iraq, and Somalia from providing effective support for the programme. In Lebanon, the programme relies on nongovernmental organisations, and government involvement has been minimal.

The programmes cannot be sustained without the support of local governments and civil society. Governments in Iran and Pakistan have provided this support. For example, in February 2006 Sindh Department of Health approved a programme of over $\$ 400000$ covering four districts in the Pakistani province. ${ }^{20}$ Several districts in the country have independently come up with their own projects, which are incorporated into the local district structure. Using the mechanism for

\section{Summary points}

Basic development needs programmes are community based initiatives that can tackle poverty, ill health, and social determents of health

Enhancing the status of women is of special relevance for programmes in the Eastern Mediterranean region

Programmes enable women to earn money and improve their access to basic physical, health, and social needs

National and local government commitment and collaboration with civil society are essential to scaling up these programmes 
community action, the Global Fund to Fight AIDS, Tuberculosis, and Malaria provided $\$ 2.7 \mathrm{~m}$ for fighting malaria and tuberculosis through the basic development needs programme in seven districts for 2005-6. ${ }^{21}$

\section{Sustaining community based initiatives}

Commitment of national and local governments, collaboration with civil society, and some form of external financial support are essential to maintain and expand these community based initiatives. Monitoring, evaluation, and documentation need to be improved to inform their further development. But care should be taken that data collection and management does not compromise the participation of community members. A feeling of ownership is essential.

Contributors and sources: All authors discussed the concept and formulation of the paper and went through the revisions. SW wrote the first draft and provided literature from the region on social determinants, MA provided basic information on the work of community based initiatives in the region, SS provided the initial conceptualisation and developed the subsequent versions. MA has been working in the area of community based initiatives since 2000; SS is the regional focal person responsible for the social determinants of health; SW is a social scientist with several years of experience in the region.

Competing interests: None declared.

1 Irwin A, Valentine N, Brown C, Loewenson R, Solar O, Brown H, et al. The Commission on Social Determinants of Health: tackling the social roots of health inequities. PloS Medicine 2006;3(6):e106.

2 Feachem RGA. Poverty and inequity: a proper focus for the new century. Bull World Health Organ 2000;78:1-2.

3 Fikree FF, Pasha O. Role of gender in health disparity: the South Asian context. BMJ 2004;328:823-6.

Yount KM. Provider bias in the treatment of diarrhea among boys and girls attending public facilities in Minia, Egypt. Soc Sci Med 2003;56:753-68.

attending public facilities in Minia, Egypt. Soc Sci Med 2003;56:753-68.
WHO Regional Office for the Eastern Mediterranean. Social and health WHO Regional Office for the Eastern Mediterranean. Social and health
indicators for countries of the Eastern Mediterranean. Cairo: EMRO, 2006.
6 League of Arab States, Republic of Yemen Ministry of Health and Population, Central Statistical Organization Yemen. Yemen family health survey: principal report 2003. Sanaa: CSO, 2005.

7 Noorbala AA, Bagheri Yadzi SA, Yasamy MT, Mohammad K. Mental health survey of the adult population in Iran. $B r J$ Psychiatry 2004;184:70-3.

8 Maziak W, Asfar T, Mzayek F, Fouad FM, Kilzieh N. Sociodemographic correlates of psychiatric morbidity among low-income women in Aleppo, Syria, Soc Sci Med 2002:54:1419-27.

9 Mohammadi MR, Ghanizadeh A, Rahgozart M, Noorbala AA, Malekafzali H, Davidian H, et al. Suicidal attempt and psychiatric disorders in Iran. Suicide Life Threat Behav 2005;35:309-16.

10 El-Zanaty F, Hussein EM, Shawky GA, Way AA, Kishor S. Egypt demographic and health survey 1995. Calverton, MD: National Population Council, Macro International, 1996.

11 Jordanian Department of Statistics, ORC Macro. Jordan population and family health survey 2002. Calverton, MD: ORC Macro, 2003.

12 Morroco Ministry of Health. Morocco demographic and health surves. 2003-4. Calverton, MD: ORC Macro, 2004

13 Mumtaza Z, Salway S. “I never go anywhere”: extricating the links between women's mobility and uptake of reproductive health services in Pakistan, Soc Sci Med 2005;60:1751-65.

14 Unicef. Innocenti digest: changing harmful social convention: female genital mutilation/cutting. Florence: Unicef Innocenti Research Centre, 2005.

15 El-Gibaly O, Ibrahim B, Mensch BS, Clark WH. The decline of female circumcision in Egypt: evidence and interpretation, Soc Sci Med 2002;54:205-20.

16 Federal Ministry of Health, Sudan. Basic development needs programme: Dar Mali village, a successful story of sustainable community development. Khartoum: Primary Health Care Support Directorate, 2003.

17 World Health Organization. Evaluation of the basic development needs programme in Djibouti, February 2005. Cairo: Eastern Mediterranean Regional Office, 2005.

18 World Health Organization. Evaluation of the basic development need programme in the Republic of Yemen. Cairo: Eastern Mediterranean Regional Office, 2005 .

19 World Health Organization. Validation of the evaluation of community based initiatives in Islamic Republic of Iran. Cairo: Eastern Mediterranean Regional Office, 2006.

20 Department of Health, Government of Sindh. PC-I proforma of the strengthening of the basic development needs programme in Sindh, July 2005 June 2008. Karachi: $\mathrm{DoH}, 2006$.

June 2008. Karachi: DoH, 2006.
Global Fund to Fight AIDS, Tuberculosis, and Malaria. Application form for the proposal to Global Fund. CCM Pakistan proposal round three. Geneva, 2003. www.theglobalfund.org/search/docs/3PKSM_698_0_full.pdf (accessed 28 Sep 2006).

doi $10.1136 /$ bmj.38988.607836.68

\title{
Regional collaboration in the Middle East to deal with H5N1 avian flu
}

\author{
Alex Leventhal, Assad Ramlawi, Adel Belbiesi, Ran D Balicer
}

In 2005-6 Arab and Israeli collaboration contained outbreaks of avian flu in the Middle East. This initiative shows how building relationships through joint efforts creates an infrastructure for cross border collaboration during emergencies

Israel Ministry of Health, PO Box 1176 , Jerusalem 91010, Israel

Alex Leventhal director of public health services

Palestinian

Authority Ministry of Health, Ramallah, West Bank

Assad Ramlawi director general of primary care and public health

continued over
Recent emerging infectious diseases have changed the way that outbreaks are dealt with-from a mainly local approach to a regional and even global one. The importance of global collaboration orchestrated by the World Health Organization has been demonstrated during recent outbreaks of severe acute respiratory syndrome and avian flu. ${ }^{12}$

We describe an example of Arab and Israeli collaboration in the Middle East on a public health issue. Cooperation between Israeli, Jordanian, and Palestinian veterinary and public health services contained outbreaks of $\mathrm{H}_{5} \mathrm{~N} 1$ avian flu. The measures taken enabled these countries to avoid human infection, increased public confidence, and reduced potential adverse outcomes of the outbreaks. This success shows how building professional and personal relationships through joint efforts for tackling common infectious diseases creates an infrastructure for cross border collaboration during emergencies.

\section{Geopolitical circumstances in the Middle East}

Jordan, the Palestinian Authority, and Israel border one another. The distance between the three capital cities is less than $80 \mathrm{~km}$. Palestinians who live in all three countries have close family and commercial ties with each other. The citizens of these countries live as one "epidemiological family"."

See table on bmj.com 